\title{
COMPLETE LARVAL DEVELOPMENT OF PHILOCHERAS MONACANTHUS FROM LABORATORY CULTURE, WITH A KEY TO THE ZOEAE OF THE EUROPEAN SPECIES OF THE GENUS (DECAPODA: CARIDEA: CRANGONIDAE)
}

\author{
J. I. González-Gordillo, A. dos Santos, and A. Rodríguez \\ (JIGG, AR) Instituto de Ciencias Marinas de Andalucía (CSIC), Polg Río San Pedro, s/n, \\ E-11510 Puerto Real (Cádiz) Spain (JIGG e-mail: nacho.gonzalez@icman.csic.es); \\ (AdS) Instituto de Investigação das Pescas e do Mar (IPIMAR), Avd de Brasilia, \\ s/n. P-1400 Lisboa, Portugal
}

\section{A B S T R A C T}

\begin{abstract}
Five zoeal stages and the first juvenile stage of the crangonid shrimp Philocheras monacanthus are described and illustrated from laboratory-reared specimens. Development to the first juvenile stage took 15 days at $18^{\circ} \mathrm{C}$ and $36 \%$ salinity. Larval morphology is compared with that of other described species of Philocheras, and a provisional key is provided.
\end{abstract}

One major problem in the study of decapod crustacean larvae is the accurate identification of specimens, since a prior knowledge of larval forms in the sampling area is required. In most cases, the proportion of species successfully identified is under $80 \%$. For example, in the Gulf of Cádiz (Southwestern Iberian Peninsula), no larval stage has been described for more than $31 \%$ of the decapod species recorded. The confusion arising from the lack of descriptions and keys is worse when descriptions are based on individuals from plankton samples, where the possibility of ascribing specimens to wrong species exists (Christiansen, 1973). Correct identification of different taxa in their larval form is essential for studies related to population estimates, spatiotemporal distributions, and other ecological aspects (e.g., Anger et al., 1994; Queiroga et al., 1994). Many comparative and phylogenetic studies also require detailed descriptions of laboratory-reared larvae, and standardization in larval descriptions is advisable (Clark et al., 1998).

Off the European coast, the family Crangonidae is represented by 19 or 20 species belonging to 7 genera, of which 6 or 7 species have been ascribed to the genus Philocheras (see Noël, 1992). For P. bispinosus neglectus (Sars) (see Pike and Williamson, 1961) and P. trispinosus (Hailstone) (see Pessani and Godino, 1991) the full larval development has been described from reared larvae.
Largely complete or plankton-based larval descriptions are available for P. bispinosus bispinosus (Hailstone) (see Sars, 1890; Webb, 1921, as Cheraphilus nanus (Krøyer); Williamson, 1915, as Crangon nanus (Krøyer); Lebour, 1931; Kurian, 1956; Pike and Williamson, 1961), P. echinulatus (see Sars, 1890, as Cheraphilus echinulatus (Sars); Williamson, 1915, as Crangon echinulatus), P. fasciatus (Risso) (see Gurney, 1903; Williamson, 1915, as Crangon fasciatus; Webb, 1921, as Aegeon fasciatus; Lebour, 1931), and P. sculptus (Bell) (see Lebour, 1931; Kurian, 1956; Williamson, 1960). The larval stages for $P$. monacanthus (Holthuis) are unknown.

The present study was undertaken to describe the larval development of $P$. monacanthus, and to compare it to that of other species of Philocheras with known larvae in order to facilitate the identification of unknown planktonic larvae.

\section{MATERIALS AND METHODS}

One ovigerous shrimp was caught in December 1996 with a benthic trawl at $4-5 \mathrm{~m}$ depth off Valdelagrana Beach in Cádiz Bay $\left(36^{\circ} 34.24^{\prime} \mathrm{N}, 06^{\circ} 14.19^{\prime} \mathrm{W}\right.$, southwestern Iberian Peninsula). The specimen was maintained in a 1,000-ml glass beaker containing well-aerated, filtered, natural sea water (36\%o) until hatching. No food was added.

After hatching, actively swimming larvae were transferred to 500-ml glass bowls with aeration at constant temperature $\left(18^{\circ} \mathrm{C}\right)$. The water was changed daily, and larvae were checked for evidence of molting. The first 2 


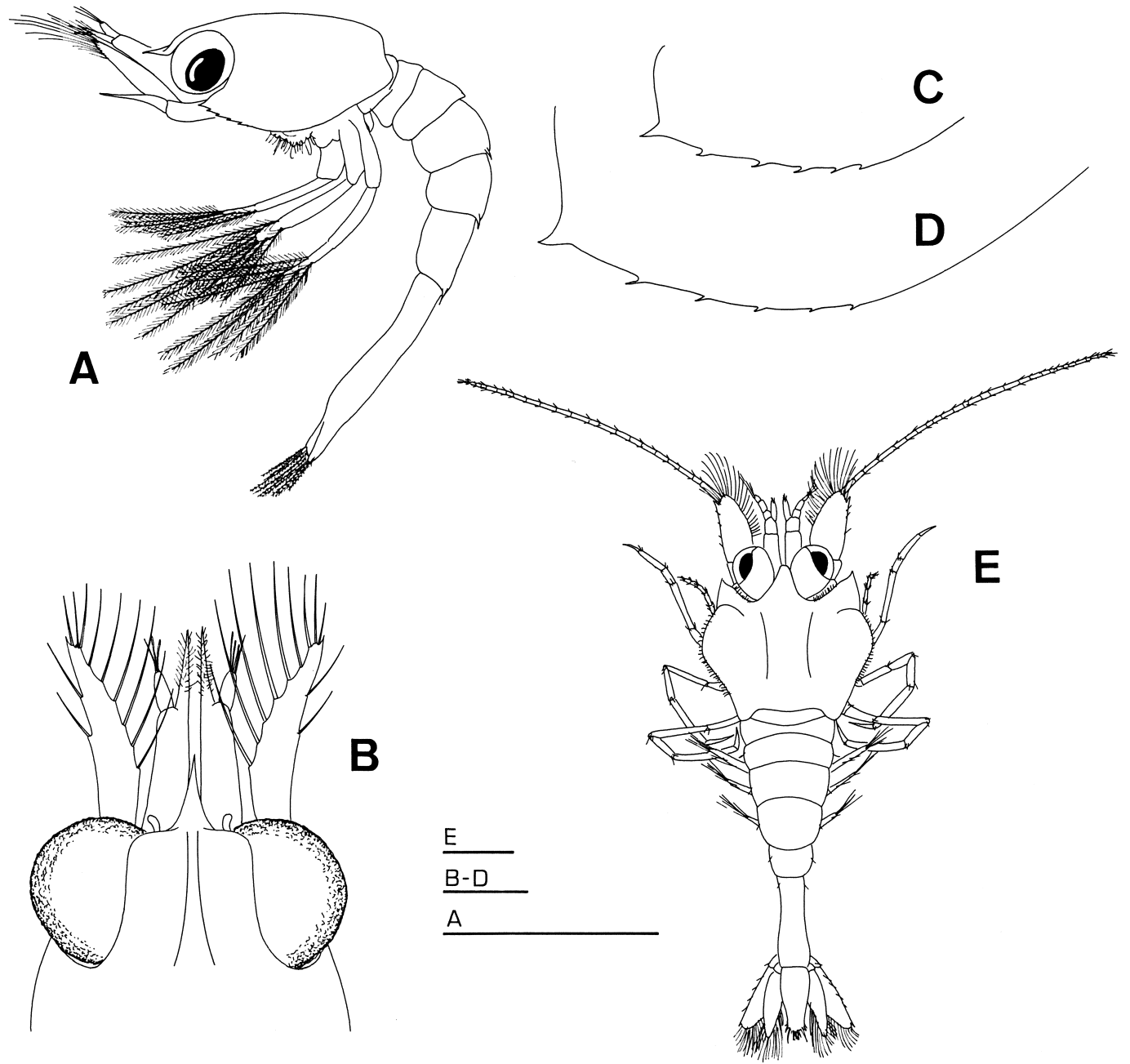

Fig. 1. Philocheras monacanthus. A, zoea I, lateral view; B, zoea I, anterior dorsal view; C, zoea II, ventral margin of carapace; D, zoea V, ventral margin of carapace; E, postlarval stage, dorsal view. Scale bars $=500 \mu \mathrm{m}(\mathrm{A}, \mathrm{E})$ and $100 \mu \mathrm{m}(\mathrm{B}, \mathrm{C}, \mathrm{D})$.

days after hatching, larvae were fed with a mixture of the alga Nannochloropsis gaditana Lubian, the rotifer Brachyonus plicatilis Müller, and after that with nauplii of Artemia. Each time the water was renewed, 3 or 4 larvae were preserved in $4 \%$ Formalin.

Descriptions of different instars were based on at least 10 specimens of each larval and juvenile stage. The appendages were dissected in sea water, mounted in lactophenol and drawn using an interference phase microscope (Zeiss Axioscop) with camera lucida. General recommendations proposed by Clark et al. (1998) for standardization in larval descriptions were followed. Features of different types of setae were mainly based on Lavalli and Factor (1992).

Carapace length was measured from the tip of the rostral spine to the posterior carapace margin. The sizes given are the arithmetic mean $\pm 95 \%$ confidence inter- vals. The spent females and complete larval series have been deposited in the Instituto de Ciencias Marinas de Andalucía (CSIC) in Cádiz, Spain (number 7CG/1996).

\section{RESULTS}

Five zoeal stages before the juvenile stage were observed in the larval development of P. monacanthus. At $18^{\circ} \mathrm{C}$ and $36 \%$ o the first juvenile stage appeared at 15 days after hatching. The major features of each larval stage and changes in appendage setation follow. Details of the type and distribution of setae and spines are given in Tables 1 and 2 . 

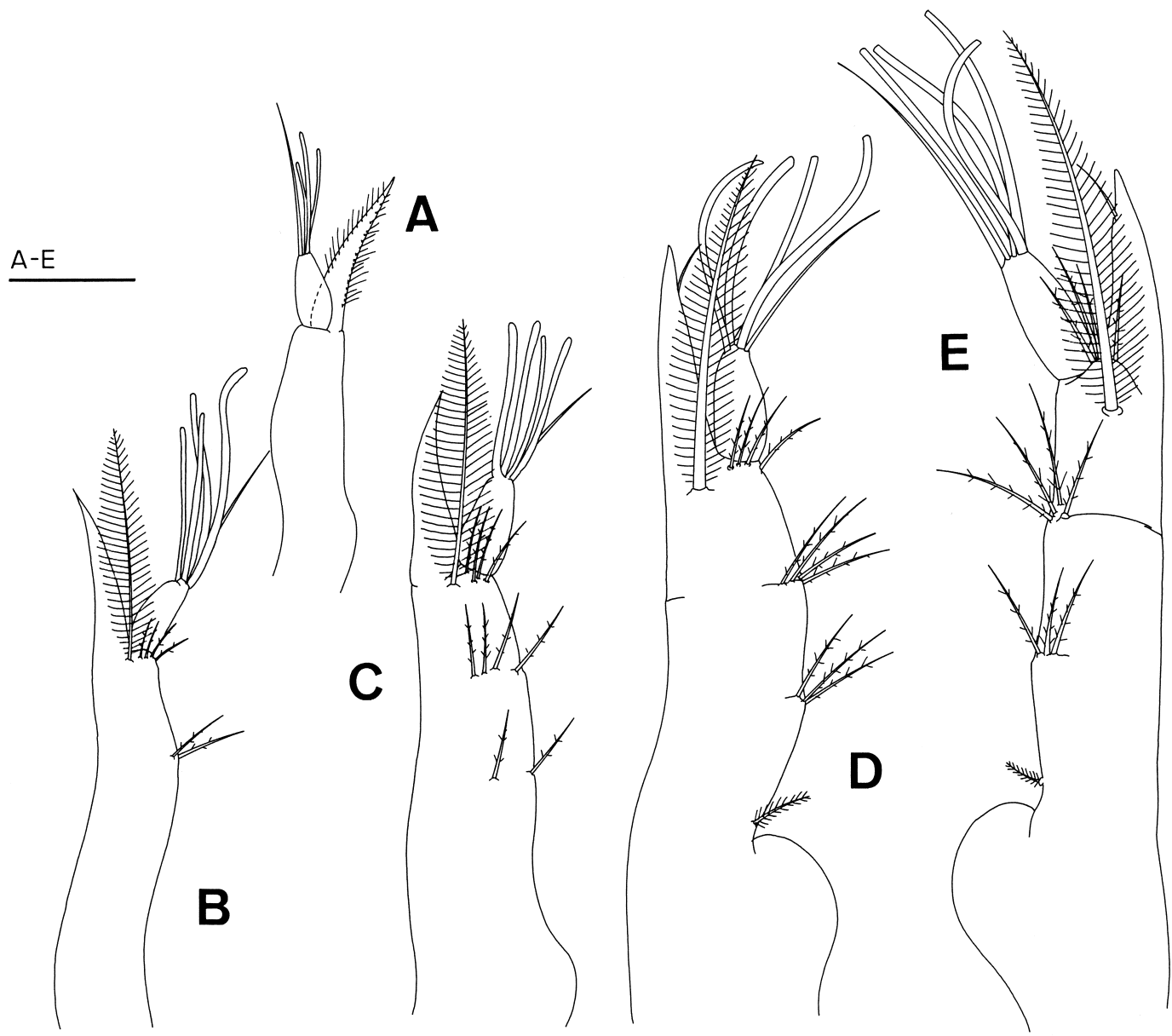

Fig. 2. Philocheras monacanthus, antennule. A, zoea I; B, zoea II; C, zoea III; D, zoea IV; E, zoea V. Scale bar = $100 \mu \mathrm{m}$.

Philocheras monacanthus (Holthuis, 1961)

Figs. 1-13, Tables 1, 2

General Morphology of Zoeal Stages

Carapace (Fig. 1A-D).-All stages bearing sharp rostrum extending beyond eyes; with pterygostomian and 4 or 5 anteroventral spines.

Antennule (Fig. 2).-Unsegmented peduncle with long, distal conical process bearing many setae in first stage. Setose exopod unsegmented in all stages, reaching at least to middle of conical process of peduncle.

Antenna (Fig. 3).-Endopod armed with rows of spinules, best developed in the first two stages. Setose scaphocerite (exopod) unsegmented and elongated.

Mandible (not shown).-Without palp, incisor and molar processes.

Maxillule (Fig. 4).-Coxal endite bilobed, setation remaining unchanged for all stages. Endopod 2-segmented, numbers of setae unchanged for all zoeae.

Maxilla (Fig. 5).-With setose bilobed coxal and basal endites. Unsegmented endopod 4-lobed, setation unchanged.

First Maxilliped (Fig. 6).--Setose endopod 3-segmented, not reaching middle of exopod. Exopod unsegmented, setation of stages 1 and 2 and 3-5 unchanged. 

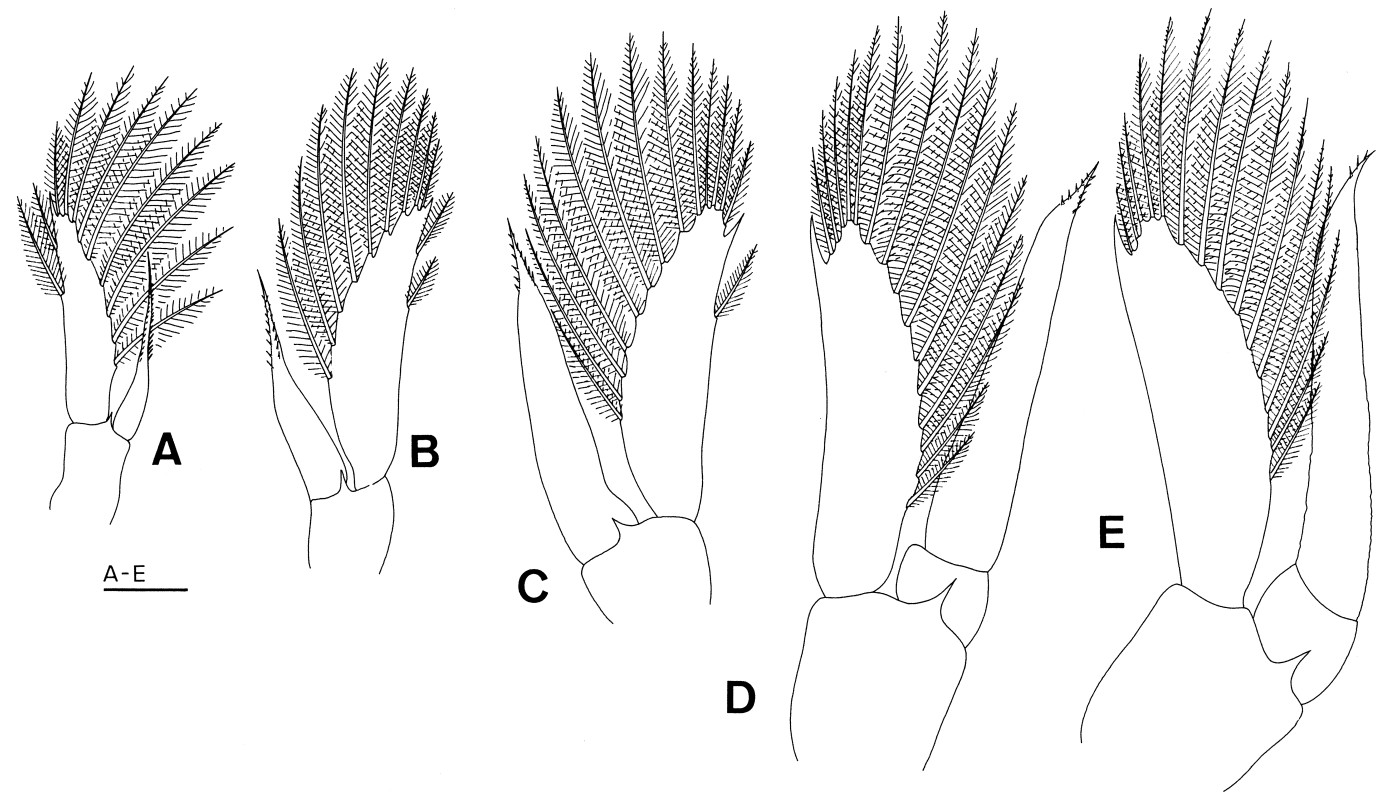

Fig. 3. Philocheras monacanthus, antenna. A, zoea I; B, zoea II; C, zoea III; D, zoea IV; E, zoea V. Scale bar = $100 \mu \mathrm{m}$.

Second Maxilliped (Fig. 7).-Coxa and basis with setation constant in zoeal stages. Endopod 4-segmented in first stage, 5-segmented in remaining zoeal stages; setose endopod extending beyond middle of exopod. Setose exopod unsegmented.

Third Maxilliped (Fig. 8).-Coxa naked. Basis with setation constant in all zoeal stages. Endopod 4-segmented in first stage and 5-segmented in other stages. Exopod unsegmented.

Pereiopods (Figs. 9 and 10).-Progressive development throughout zoeal stages. First to fifth pereiopod fully developed from fourth zoeal stage. First and second pereiopods biramous and third to fifth pereiopods uniramous.

Abdomen and Telson (Fig. 11).-Five somites and telson in 2 first stages, sixth additional somite in subsequent stages. Dorsal spines on somites III-V. Telson with distal setose margin slightly curved, with shallow median indentation except for first stage.

\section{General Morphology of} First Juvenile Stage

Carapace Length. $-1.109 \pm 0.050 \mathrm{~mm}$.
Caparace (Fig. 1E).- - Rostrum short, with rounded apex. Eyes stalked. Orbital and lateral margins bearing fine setae. Ventrolateral margin without spination.

Antennule (Fig. 13F).- Smaller than antenna. Peduncle and endopod 3-segmented, latter with 4 aesthetascs on distal segment. Placement and number of other setae as shown.

Antenna (Fig. 13G).-Basis with 2 long and 2 short plumose setae. Endopod 20-segmented, with 3 or 4 short simple setae per segment. Scaphocerite with 19 plumose setae plus 1 simple seta, and 3 shorter setae on outer margin.

Maxillule (Fig. 12A).—Coxa with 4 sparsely plumose setae. Basis with 6 strong, plumodenticulate cuspidate setae and 6 sparsely plumose setae. Unsegmented endopod bearing simple seta distally.

Maxilla (Fig. 12B).-Endites coxal and basal reduced to single lobe, bearing 1 sparsely plumose seta. Endopod unsegmented, with 1 plumose seta on outer margin and 1 sparsely plumose seta distally. Scaphognathite with 25-27 plumose setae. 


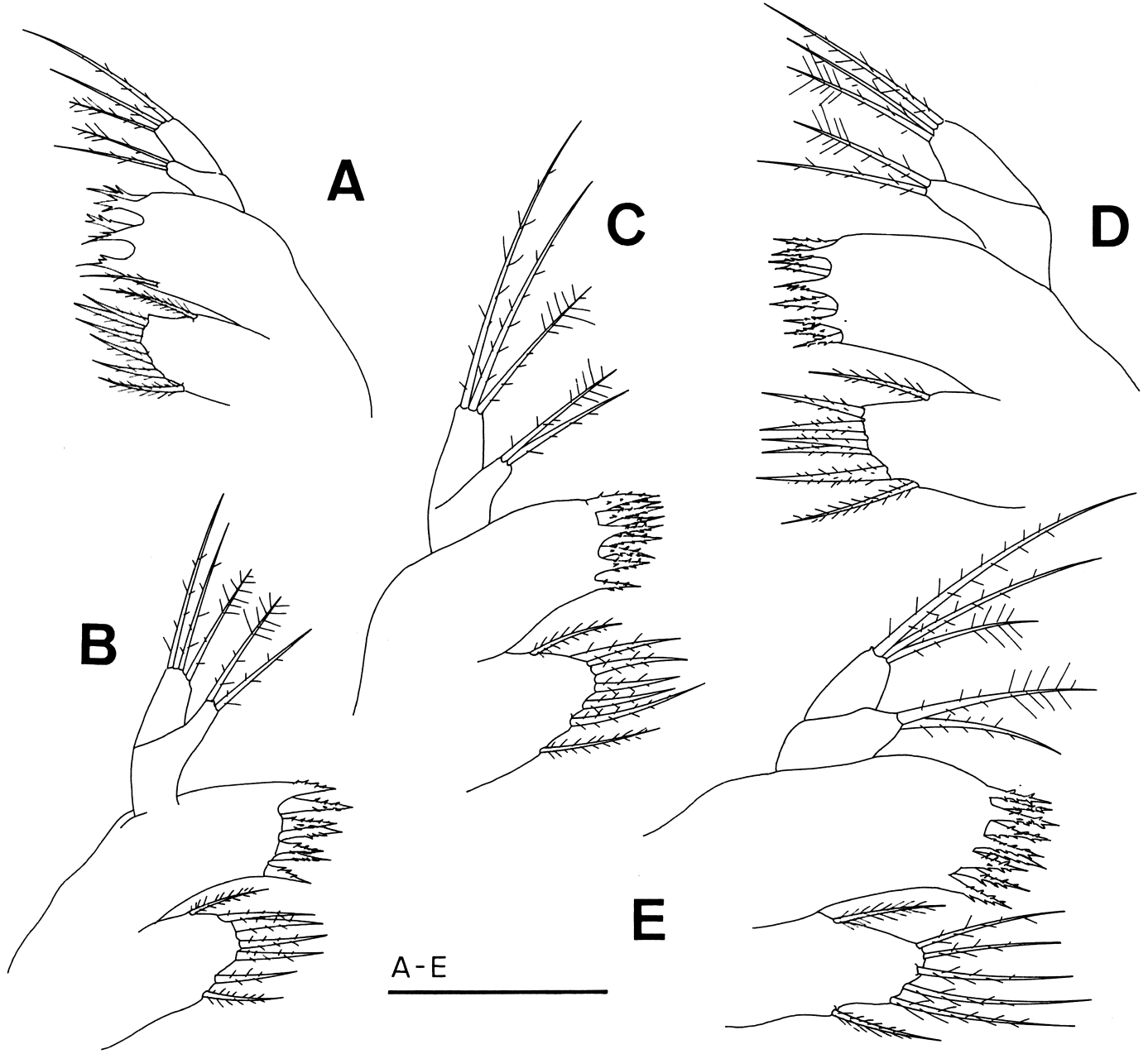

Fig. 4. Philocheras monacanthus, maxillule. A, zoea I; B, zoea II; C, zoea III; D, zoea IV; E, zoea V. Scale bar = $100 \mu \mathrm{m}$.

First Maxilliped (Fig. 12C).-Basally with developing epipodite. Basis naked. Unsegmented endopod with 4 plumose setae. Exopod 2-segmented with 1 sparsely plumose seta and 6 plumose setae, respectively.

Second Maxilliped (Fig. 12D).-Basis bearing 2 sparsely plumose setae. Endopod 5-segmented, with first 3 segments naked. Fourth segment with 4 sparsely plumose setae and 4 serrulate setae. Fifth segment with 4 sparsely plumose setae, 3 plumodenticulate setae, and 2 serrulate setae. Exopod 2-segmented with 8 plumose setae on distal segment.

Third Maxilliped (Fig. 12E).-Coxa with plumose seta. Basis with 10 simple setae on inner margin. Endopod 3-segmented, with se- tal placement as shown. Exopod 2-segmented with 8 plumose setae on distal segment.

Pereiopods (Fig. 13A-E).-All uniramous and 5-segmented. Number and placement of setae as shown.

Abdomen.-Without spines on dorsal margin but with paired setae on somites II-VI.

Pleopods (Fig. 12F).-Functional and biramous. Coxa with plumose seta. Basis with 2 setae. Small endopods each bearing sparsely setose seta. Exopod with 12 or 13 plumose setae.

Telson (Fig. 13H).-Bearing 3 spines on each lateral margin, 6 simple and 2 plumodenticulate setae on posterior margin. 


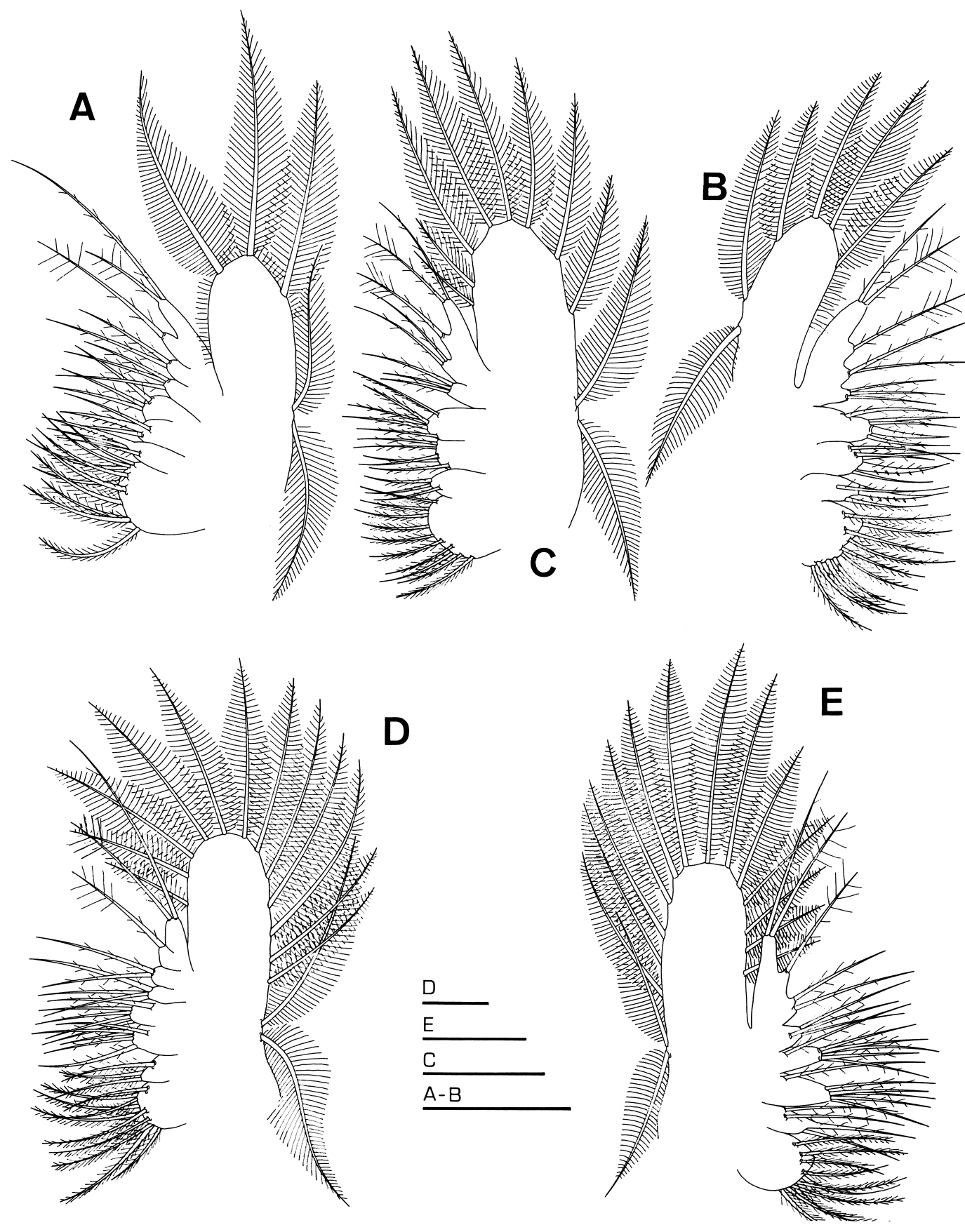

Fig. 5. Philocheras monacanthus, maxilla. A, zoea I; B, zoea II; C, zoea III; D, zoea IV; E, zoea V. Scale bars = $100 \mu \mathrm{m}$.

Key to Zoeal Stages of SPECIES OF PHILOCHERAS

1. Abdominal somites with spines .

- Abdominal somites without spines
2. Length of antennule conical process at most 1.5 times exopod length ......... P. bispinosus neglectus

- Length of antennule conical process at least 1.5 times exopod length P. trispinosus (North Atlantic form) 

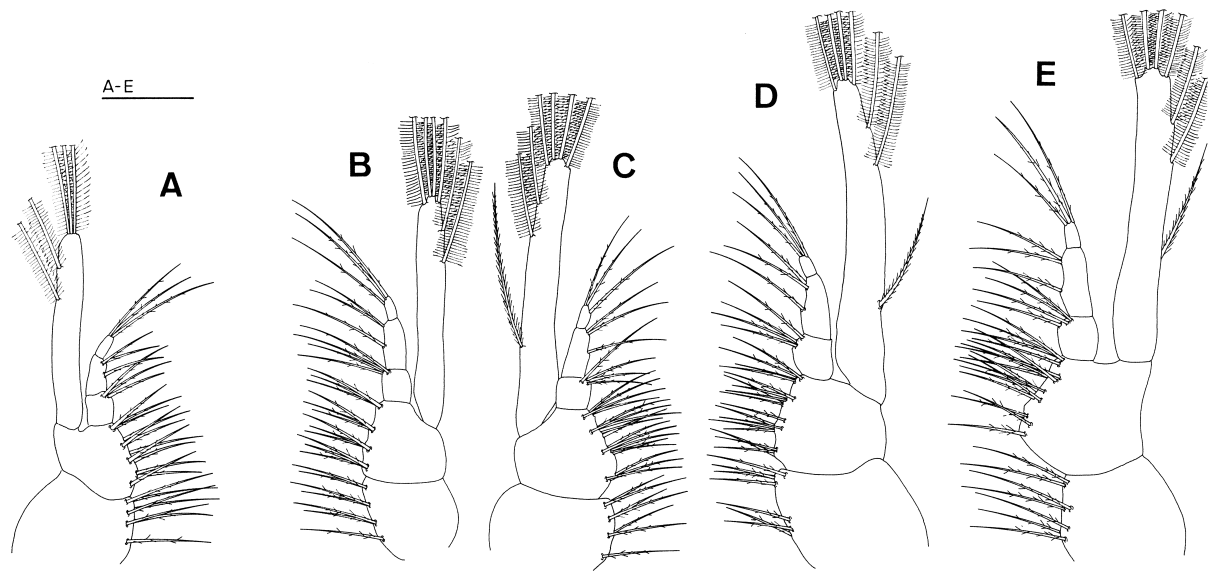

Fig. 6. Philocheras monacanthus, first maxilliped. A, zoea I; B, zoea II; C, zoea III; D, zoea IV; E, zoea V. Scale bar $=100 \mu \mathrm{m}$.

Table 1. Setation and other characteristics of zoeal stages I, II, and III of Philocheras monacanthus. a, aesthetasc; b, abdominal spine; c, spine; d, plumodenticulate seta; e, sparsely plumose seta; g, degenerated aesthetasc; $j$, spiny projection; $n$, plumose natatory seta; $\mathrm{p}$, plumose seta; $r$, degenerate plumose seta; $s$, simple seta; $t$, plumodenticulate cuspidate setae.

\begin{tabular}{|c|c|c|c|}
\hline \multirow[b]{2}{*}{ Features } & \multicolumn{3}{|c|}{ Stages } \\
\hline & Zoea I & Zoea II & Zoea III \\
\hline Carapace length (mm) & $0.711 \pm 0.017$ & $0.846 \pm 0.012$ & $0.952 \pm 0.010$ \\
\hline Eyes & sessile & stalked & stalked \\
\hline \multicolumn{4}{|l|}{ Antennule } \\
\hline peduncle (excluding conical process) & naked & $2 e+4 e+1 p$ & $2 e+4 e+4 e+1 p$ \\
\hline exopod & $3 a+1 s$ & $4 a+1 s$ & $4 a+1 s$ \\
\hline \multicolumn{4}{|l|}{ Antenna } \\
\hline peduncle & $1 \mathrm{c}$ & $1 \mathrm{c}$ & $1 \mathrm{c}$ \\
\hline endopod & unsegmented & unsegmented & unsegmented \\
\hline scaphocerite & $9 p+1 j+2 p$ & $9 p+1 j+2 p$ & $13 p+1 j+1 p$ \\
\hline \multicolumn{4}{|l|}{ Maxillule } \\
\hline coxal endite & $7 e$ & $7 \mathrm{e}$ & $7 \mathrm{e}$ \\
\hline basal endite & $5 t+1 e$ & $7 \mathrm{t}$ & $9 \mathrm{t}$ \\
\hline endopod & $2 \mathrm{e}, 3 \mathrm{e}$ & $2 \mathrm{e}, 3 \mathrm{e}$ & $2 \mathrm{e}, 3 \mathrm{e}$ \\
\hline \multicolumn{4}{|l|}{ Maxilla } \\
\hline coxal endite & $10 p+3 p$ & $10 p+3 e$ & $10 p+3 p$ \\
\hline basal endite & $3 e+3 e$ & $5 e+5 e$ & $5 e+5 e$ \\
\hline endopod & $3 e+2 e+1 e+2 e$ & $3 e+2 e+1 e+2 e$ & $3 e+2 e+1 e+2 e$ \\
\hline scaphognathite & $3 p+2 p$ & $4 p+2 p$ & $8 p+2 p$ \\
\hline \multicolumn{4}{|l|}{ First maxilliped } \\
\hline coxa & $7 \mathrm{e}$ & $7 \mathrm{e}$ & $7 \mathrm{e}$ \\
\hline basis & $12 \mathrm{e}$ & $12 \mathrm{e}$ & $17 \mathrm{e}$ \\
\hline endopod & $3 e, 1 e+2 e, 3 e$ & $4 \mathrm{e}, 1 \mathrm{e}+2 \mathrm{e}, 3 \mathrm{e}$ & $4 \mathrm{e}, 1 \mathrm{e}+2 \mathrm{e}, 3 \mathrm{e}$ \\
\hline exopod & $1 n+1 n+3 n$ & $1 n+1 n+4 n$ & $1 p+1 n+1 n+4 n$ \\
\hline \multicolumn{4}{|l|}{ Second maxilliped } \\
\hline coxa & $1 \mathrm{e}$ & $1 \mathrm{e}$ & $1 \mathrm{e}$ \\
\hline basis & $8 \mathrm{e}$ & $8 \mathrm{e}$ & $8 \mathrm{e}$ \\
\hline endopod & $3 \mathrm{e}, 1 \mathrm{e}, 2 \mathrm{e}, 4 \mathrm{e}$ & $3 e+1 p, 1 e, 0,3 e, 5 e$ & $3 e+1 p, 1 e+1 p, 0,3 e, 6 e+1 p$ \\
\hline exopod & $2 n+2 n+3 n$ & $2 n+2 n+4 n$ & $2 n+2 n+4 n$ \\
\hline \multicolumn{4}{|l|}{ Third maxilliped } \\
\hline basis & $2 \mathrm{e}$ & $2 \mathrm{e}$ & $2 \mathrm{e}$ \\
\hline endopod & $1 \mathrm{e}, 1 \mathrm{e}, 2 \mathrm{e}, 1 \mathrm{p}+3 \mathrm{e}$ & $1 \mathrm{e}, 1 \mathrm{e}, 0,2 \mathrm{e}, 1 \mathrm{p}+3 \mathrm{e}$ & $1 \mathrm{e}, 1 \mathrm{e}, 0,1 \mathrm{~s}+2 \mathrm{e}, 1 \mathrm{p}+4 \mathrm{e}$ \\
\hline exopod & $2 n+2 n+3 n$ & $2 n+2 n+4 n$ & $2 n+2 n+4 n$ \\
\hline First pereiopod & small buds & end.: $3 \mathrm{e}$ & end.: $1 \mathrm{e}+3 \mathrm{e}$ \\
\hline Second pereiopod & absent & $\begin{array}{c}\text { exo.: } \ln +2 n+4 n \\
\text { absent }\end{array}$ & $\begin{array}{l}\text { exo.: } \ln +2 n+4 n \\
\text { rudimentary }\end{array}$ \\
\hline \multicolumn{4}{|l|}{ Abdomen } \\
\hline somites & $0,0,2 b, 2 b, 2 b$ & $0,0,2 b, 2 b, 2 b$ & $0,0,2 b, 2 b, 2 b, 0$ \\
\hline pleopods & absent & absent & small buds \\
\hline \multirow{2}{*}{\multicolumn{4}{|c|}{ uropods }} \\
\hline & & & \\
\hline endopod & absent & absent & naked \\
\hline exopod & absent & absent & $8 p$ \\
\hline
\end{tabular}



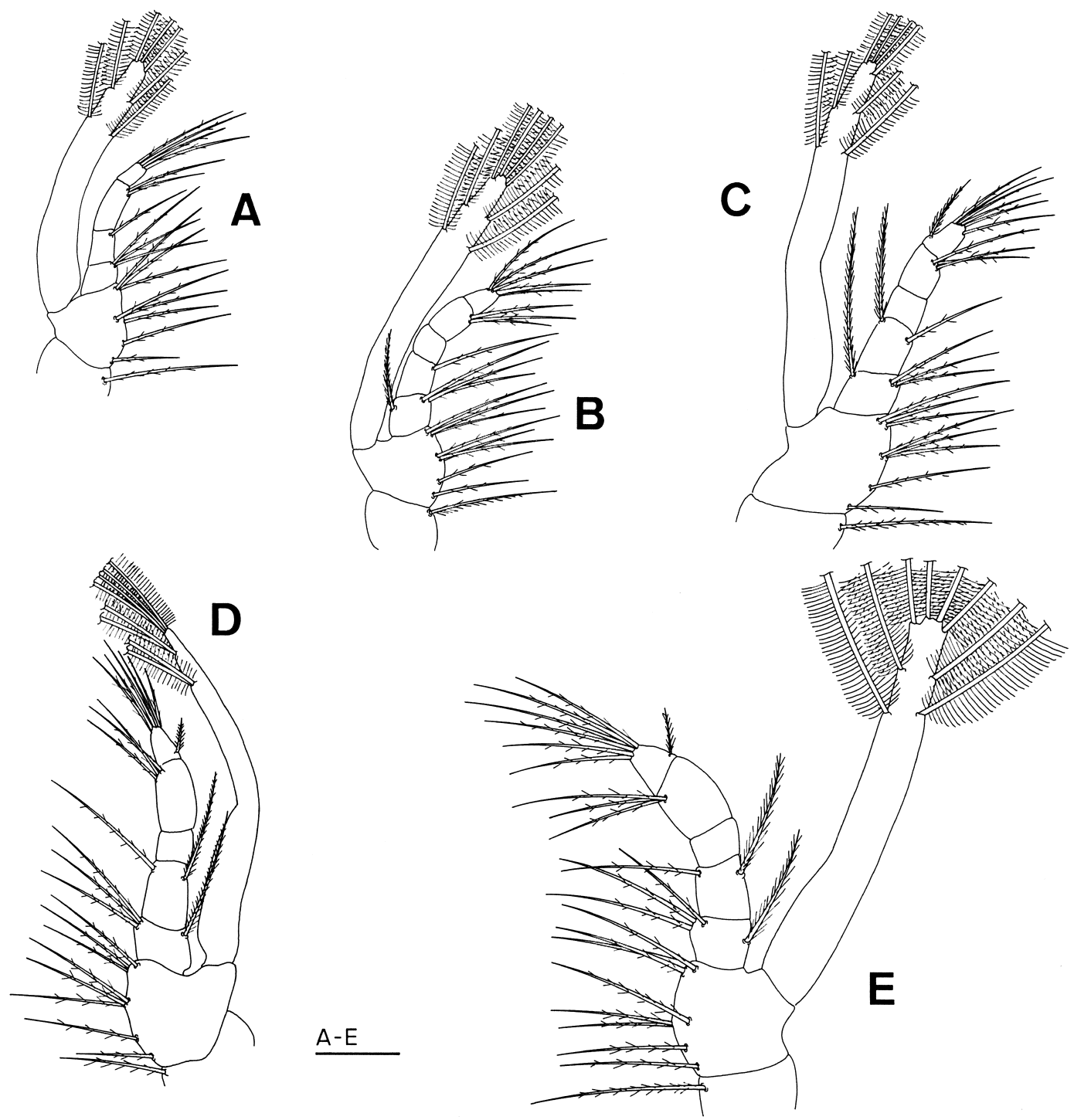

Fig. 7. Philocheras monacanthus, second maxilliped. A, zoea I; B, zoea II; C, zoea III; D, zoea IV; E, zoea V. Scale bar $=100 \mu \mathrm{m}$.

3. Spines on abdominal somite 5 long and blunt; ventral margin of carapace without denticles .

$$
\text { P. fasciatus }
$$

- Spines on abdominal somite 5 small and not blunt; ventral margin of carapace with denticles ...... 4

4. Ventral margin of carapace with 8-11 denticles; antennal exopod with prominent spine .... P. sculptus

- Ventral margin of carapace with 4-6 denticles ... 5

- Ventral margin of carapace with 3 denticles

$$
\text { P. trispinosus (Mediterranean form) }
$$

5. Spines on abdominal somite 3 arising from posterior margin ................. echinulatus

- Spines on abdominal somite 3 arising above posterior margin .
6. Total length of zoeal stages $1.3-3.5 \mathrm{~mm}$; ventral margin of carapace with 4-6 denticles .

P. bispinosus bispinosus (see Discussion)

- Total length of zoeal stages 1.18-2.05 mm; ventral margin of carapace with 4 or 5 denticles .... P. monacanthus (Gulf of Cádiz) (see Discussion)

\section{DISCUSSION}

Williamson (1960) established the morphological differences between the larvae of the various genera of Crangonidae. Accordingly, Philocheras monacanthus, like other 


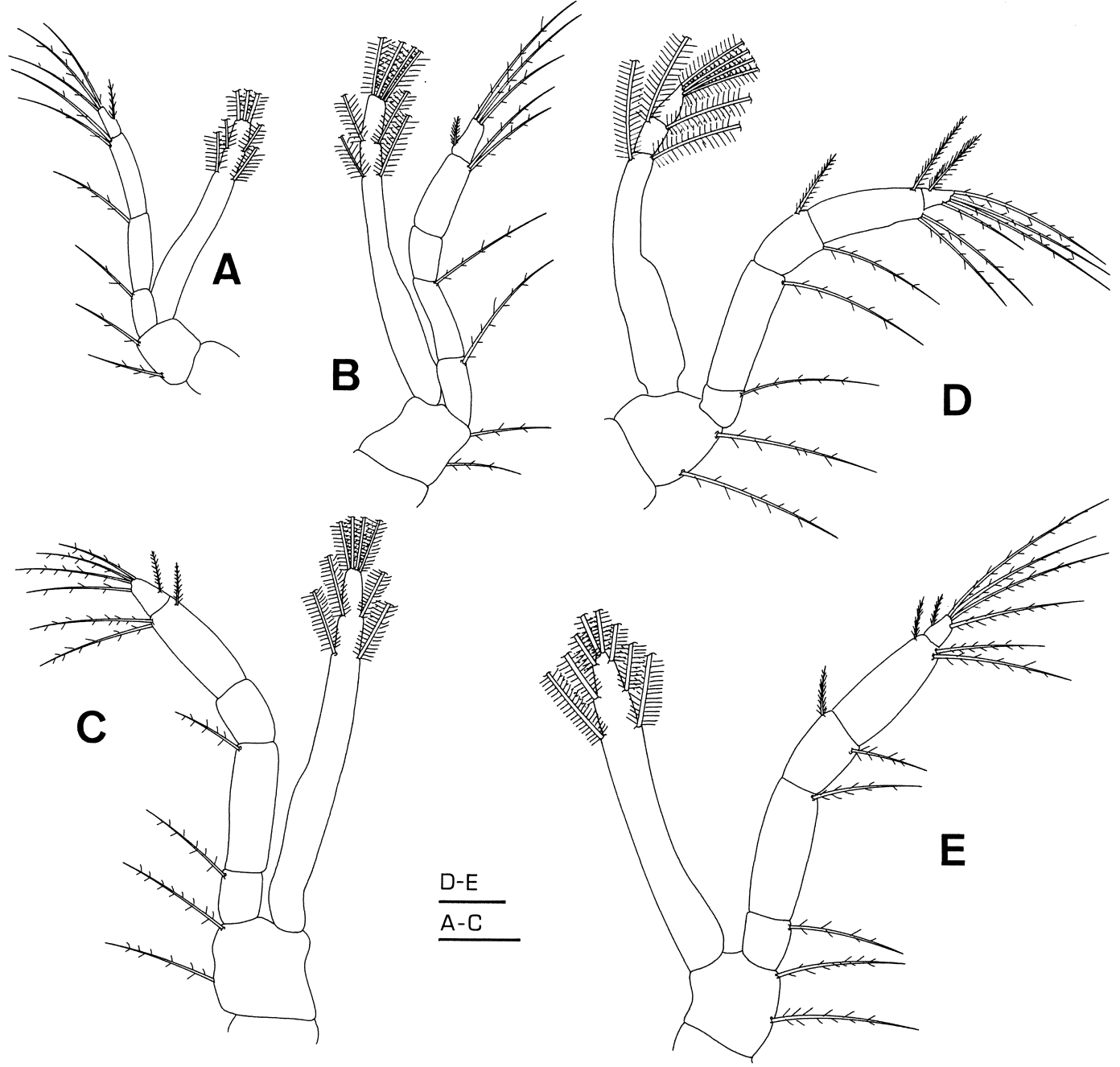

Fig. 8. Philocheras monacanthus, third maxilliped. A, zoea I; B, zoea II; C, zoea III; D, zoea IV; E, zoea V. Scale bars $=100 \mu \mathrm{m}$.

species of the genus, can be distinguished from larvae of the genus Crangon by the presence of a 2-segmented endopod on the maxillule, and by the presence of exopods on pereiopods 1 and 2, in zoeae IV and V.

The larvae of $P$. monacanthus can be separated from other congeners by the number of denticles on the ventral carapace margin, by the number, position, and form of the spines on abdominal somites, and by the relative length of the inner and outer rami of the antennule (Williamson, 1960). However, these morphological characters are insufficient to separate $P$. bispinosus bispinosus from $P$. monacanthus.
The larvae of $P$. monacanthus share with $P$. bispinosus bispinosus the number of spines on somites III-V, and the same position of spine insertion on the third somite. In addition, the larvae of $P$. bispinosus bispinosus have 4-6 denticles on the ventral margin of the carapace, compared to 4 or 5 in $P$. monacanthus, and the relation between the two rami of the antennule is the same between these two species. Based on only these morphological characters, it is not possible to separate the two species. However, the description of the larval development of $P$. bispinosus bispinosus is incomplete, and the full description of all the stages and all the 

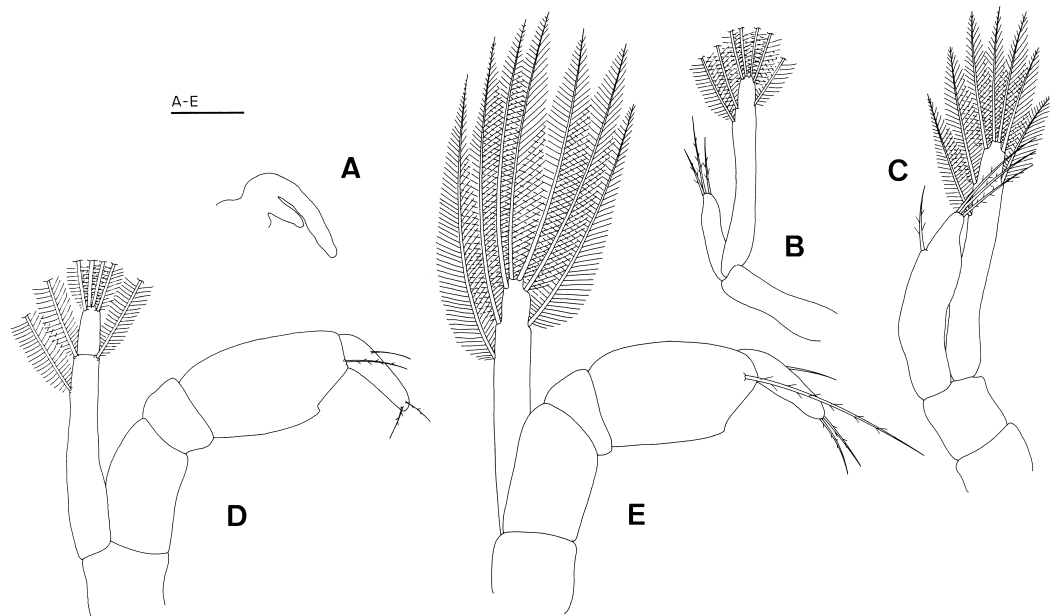

Fig. 9. Philocheras monacanthus, first pereiopod. A, zoea I; B, zoea II; C, zoea III; D, zoea IV; E, zoea V. Scale bar $=100 \mu \mathrm{m}$.

Table 2. Setation and other characteristics of zoeal stages IV and V of Philocheras monacanthus (for coding see Table 1).

\begin{tabular}{|c|c|c|}
\hline \multirow[b]{2}{*}{ Features } & \multicolumn{2}{|c|}{ Stages } \\
\hline & Zoea IV & Zoea V \\
\hline Carapace length (mm) & $0.988 \pm 0.009$ & $0.997 \pm 0.011$ \\
\hline Eyes & stalked & stalked \\
\hline \multicolumn{3}{|l|}{ Antennule } \\
\hline peduncle (excluding conical process) & $1 p+3 e+4 e+4 e+1 p+1 s$ & $1 p+3 e+4 e, 4 e+1 p+1 s$ \\
\hline exopod & $4 a+1 s$ & $4 a+1 s$ \\
\hline \multicolumn{3}{|l|}{ Antenna } \\
\hline peduncle & $1 \mathrm{c}$ & $1 \mathrm{c}$ \\
\hline endopod & 2-segmented & 2-segmented \\
\hline scaphocerite & $15 p+1 j$ & $15 p+1 j$ \\
\hline \multicolumn{3}{|l|}{ Maxillule } \\
\hline coxal endite & $7 \mathrm{e}$ & $7 \mathrm{e}$ \\
\hline basal endite & $9 \mathrm{t}$ & $9 t$ \\
\hline endopod & $2 \mathrm{e}, 3 \mathrm{e}$ & $2 \mathrm{e}, 3 \mathrm{e}$ \\
\hline \multicolumn{3}{|l|}{ Maxilla } \\
\hline coxal endite & $10 p+3 p$ & $10 p+4 p$ \\
\hline basal endite & $5 e+5 e$ & $6 e+6 e$ \\
\hline endopod & $3 e+2 e+1 e+2 e$ & $3 e+2 e+1 e+2 e$ \\
\hline scaphognathite & $12 p+2 p$ & $13 p+2 p$ \\
\hline \multicolumn{3}{|l|}{ First maxilliped } \\
\hline coxa & $7 \mathrm{e}$ & $7 \mathrm{e}$ \\
\hline basis & $17 \mathrm{e}$ & $17 \mathrm{e}$ \\
\hline endopod & $4 \mathrm{e}, 1 \mathrm{e}+2 \mathrm{e}, 3 \mathrm{e}$ & $4 \mathrm{e}, 1 \mathrm{e}+2 \mathrm{e}, 3 \mathrm{e}$ \\
\hline exopod & $1 p+1 n+1 n+4 n$ & $1 p+1 n+1 n+4 n$ \\
\hline \multicolumn{3}{|l|}{ Second maxilliped } \\
\hline coxa & $1 \mathrm{e}$ & $1 \mathrm{e}$ \\
\hline basis & $8 \mathrm{e}$ & $8 \mathrm{e}$ \\
\hline endopod & $3 e+1 p, 1 e+1 p, 0,3 e, 6 e+1 p$ & $3 e+1 p, 1 e+1 p, 0,3 e, 1 e+6 e$ \\
\hline exopod & $2 n+2 n+4 n$ & $2 n+2 n+4 n$ \\
\hline \multicolumn{3}{|l|}{ Third maxilliped } \\
\hline basis & $2 \mathrm{e}$ & $2 \mathrm{e}$ \\
\hline endopod & $1 \mathrm{e}, 1 \mathrm{e}, 1 \mathrm{~s}+1 \mathrm{e}, 1 \mathrm{~s}+2 \mathrm{e}, 1 \mathrm{~s}+4 \mathrm{e}$ & $1 \mathrm{e}, 1 \mathrm{e}, 1 \mathrm{~s}+1 \mathrm{e}, 1 \mathrm{~s}+2 \mathrm{e}, 1 \mathrm{~s}+4 \mathrm{e}$ \\
\hline exopod & $2 n+2 n+4 n$ & $2 n+2 n+4 n$ \\
\hline First pereiopod & end.: $0,0,1 \mathrm{e}, 1 \mathrm{~s}+2 \mathrm{e}$ & end.: $0,0,1 \mathrm{e}, 1 \mathrm{~s}+2 \mathrm{e}$ \\
\hline & exo.: $1 n+2 n+4 n$ & exo.: $1 n+2 n+4 n$ \\
\hline \multicolumn{3}{|l|}{ Second pereiopod } \\
\hline endopod & $0,0,1 \mathrm{~s}, 1 \mathrm{~s}$ & $0,0,1 \mathrm{~s}, 2 \mathrm{~s}$ \\
\hline exopod & $1 p+4 p$ & $1 p+4 p$ \\
\hline \multicolumn{3}{|l|}{ Abdomen } \\
\hline somites & $0,0,2 b, 2 b, 2 b, 0$ & $0,0,2 b, 2 b, 2 b, 0$ \\
\hline pleopods & biramous & biramous \\
\hline \multirow{2}{*}{\multicolumn{3}{|c|}{ uropods }} \\
\hline & & \\
\hline endopod & $12 \mathrm{p}+10 \mathrm{e}$ & $12 \mathrm{e}+10 \mathrm{p}$ \\
\hline exopod & $14 p+5 e$ & $12 \mathrm{p}$ \\
\hline
\end{tabular}



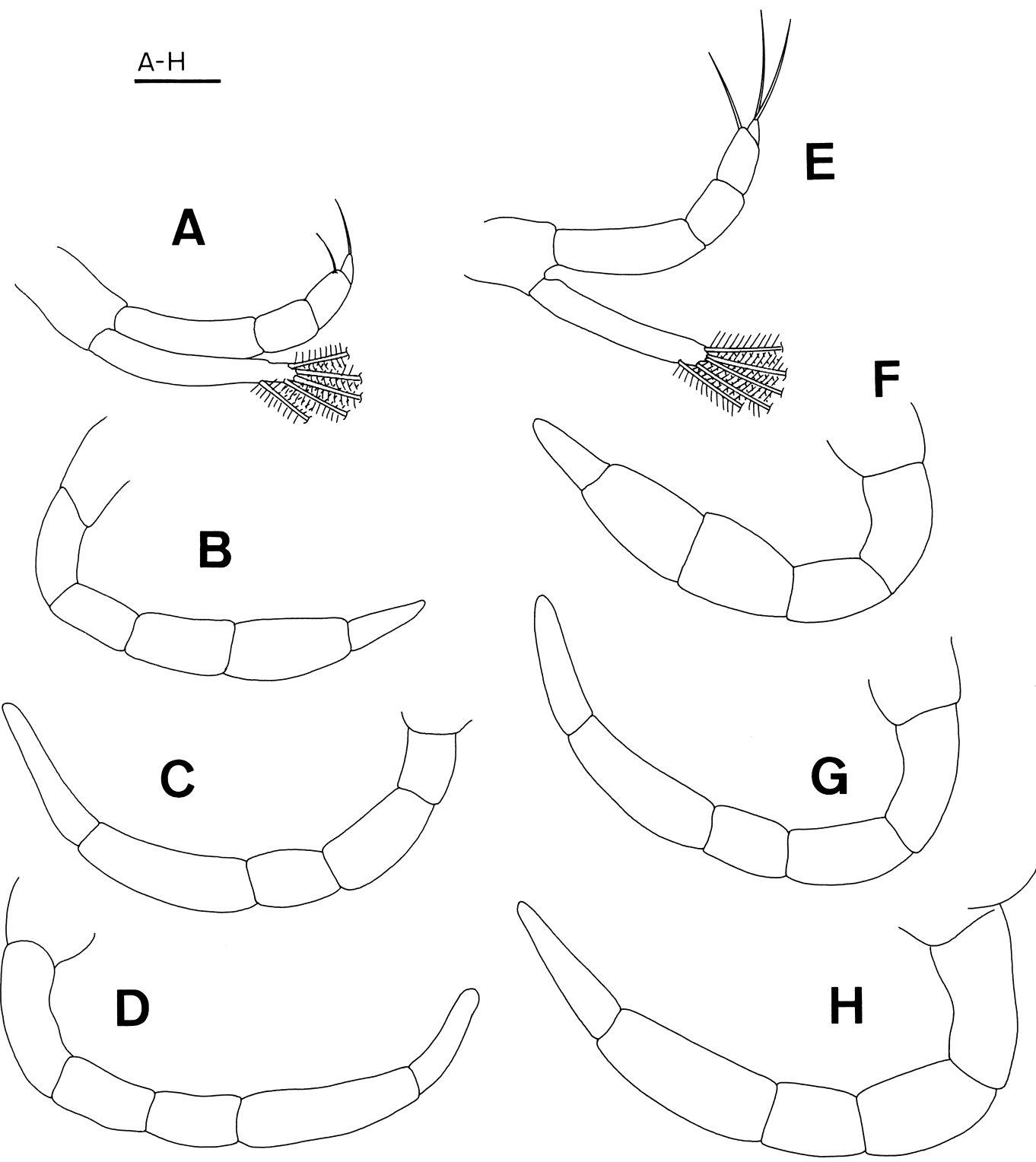

Fig. 10. Philocheras monacanthus. Zoea IV: A, second pereiopod; B, third pereiopod; C, fourth pereiopod; D, fifth pereiopod. Zoea V: E, second pereiopod; F, third pereiopod; G, fourth pereiopod; H, fifth pereiopod. Scale bar = $100 \mu \mathrm{m}$.

appendages is still unknown (Sars, 1890; Lebour, 1931; Pike and Williamson, 1961). Nevertheless, a provisional key for the genus Philocheras is presented here which includes $P$. monacanthus and thus is an improvement on the key by Williamson (1960).

By contrast, the morphological intraspecific variation within some species of Philocheras is known. For P. bispinosus, Pike and Williamson (1961) described intermediate larvae between the typical "bispinosus-form" and the typical "neglectus-form." Pessani and Godino (1991) described morphological variation for larvae of $P$. trispinosus from the Tyrrhenian Sea, Italy. These larvae are distinguished from those described by Gurney (1903) and Lebour (1931) from the British Isles by the number of ventral marginal denticles and by spines on the abdominal somites. Finally, Lebour (1931) stated that sometimes larvae of $P$. sculptus have very small dorsolateral spines on the second ab- 

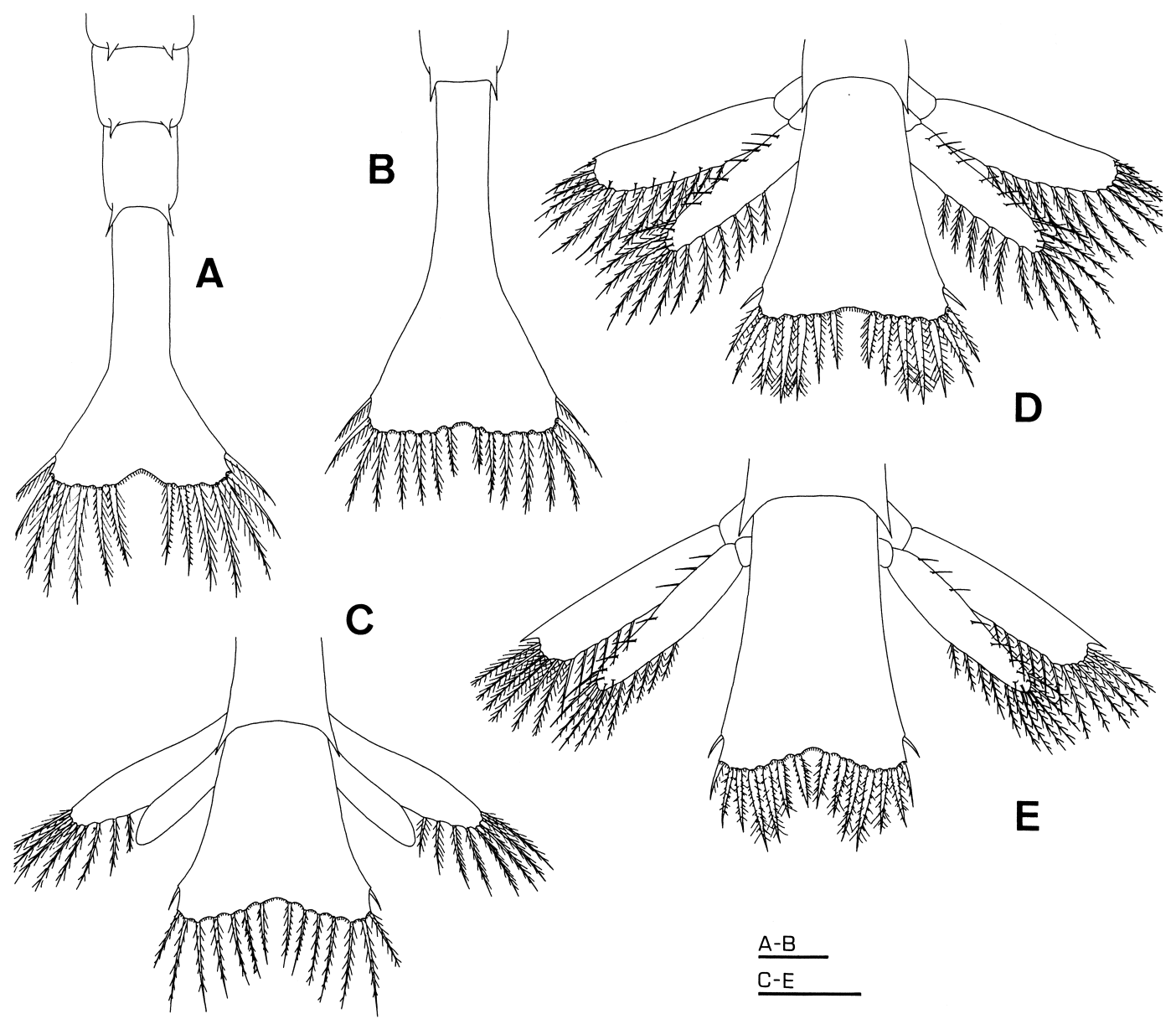

Fig. 11. Philocheras monacanthus, telson. A, zoea I; B, zoea II; C, zoea III; D, zoea IV; E, zoea V. Scale bars = $100 \mu \mathrm{m}$.

dominal somite. For P. bispinosus bispinosus and $P$. bispinosus neglectus this variation occurs in the same geographical area, whereas for P. trispinosus, it seems to occur within different areas, including the Mediterranean and the northeastern Atlantic.

Unlike the case of $P$. bispinosus, it is not possible to estimate morphological variation among larvae of $P$. monacanthus or other species of Philocheras.

Known morphological differences between species are always based on the number of denticles on the ventral margin of the carapace, and on the presence or absence of spines on abdominal somites 3-5. Larvae of $P$. monacanthus do not vary in this regard, with abdominal somites always having a pair of spines on somites III-V, and 4 or 5 denticles on the ventral margin of the carapace.

Complete laboratory rearing with full descriptions of all stages for species of Philocheras is known only for P. trispinosus (see Pessani and Godino, 1991), P. monacanthus (present work), and P. fasciatus (see González-Gordillo and Rodríguez, in preparation). Philocheras bispinosus neglectus (see Pike and Williamson, 1961) was reared in the laboratory but described only briefly. In order to improve knowledge of the morphology of the larval stages, a full description of the other species is necessary. Populations of $P$. bispinosus and $P$. monacanthus are sympatric in Mediterranean and Iberian waters from the Strait of Gibraltar to Cape S. Vicente 


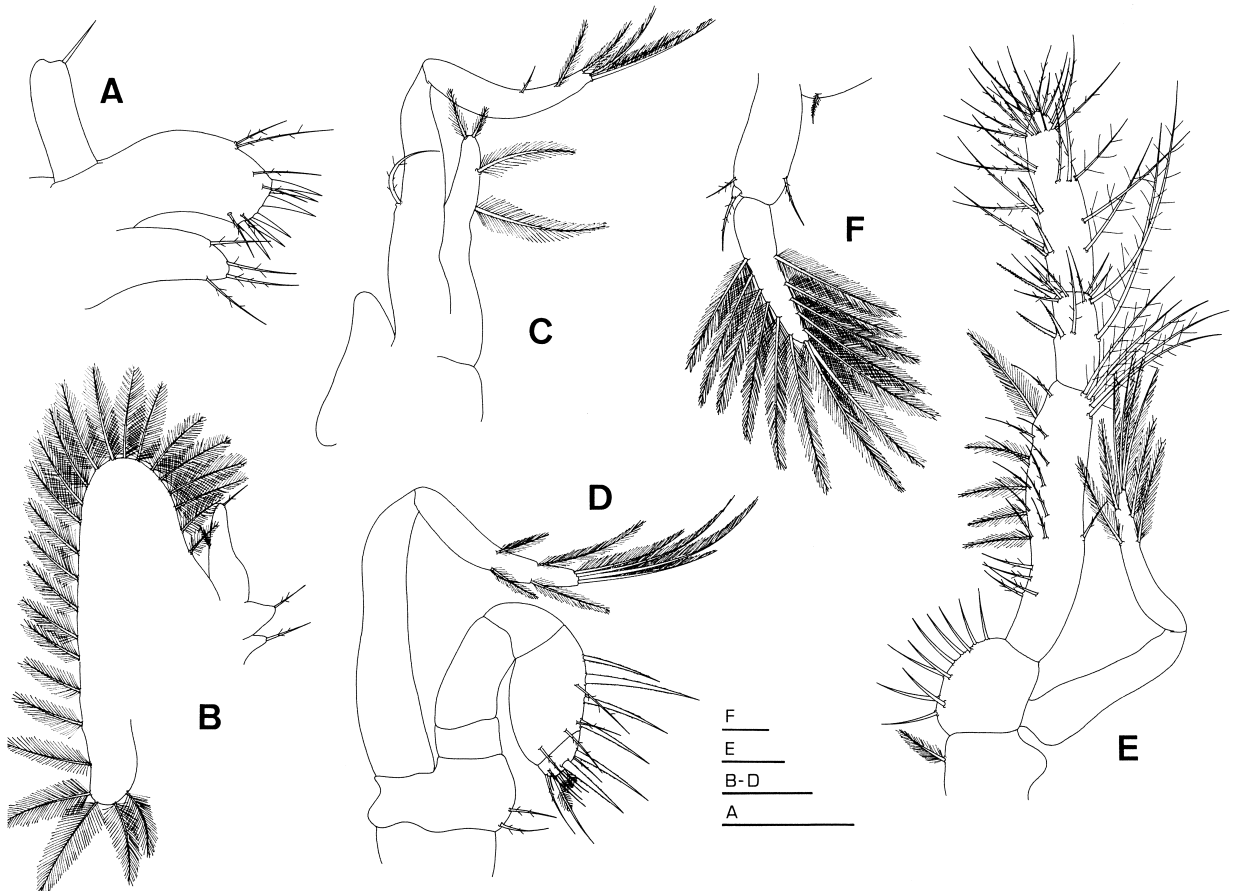

Fig. 12. Philocheras monacanthus. First juvenile stage: A, maxillule; B, maxilla; C, first maxilliped; D, second maxilliped; E, third maxilliped; F, first pleopod. Scale bars $=100 \mu \mathrm{m}$.
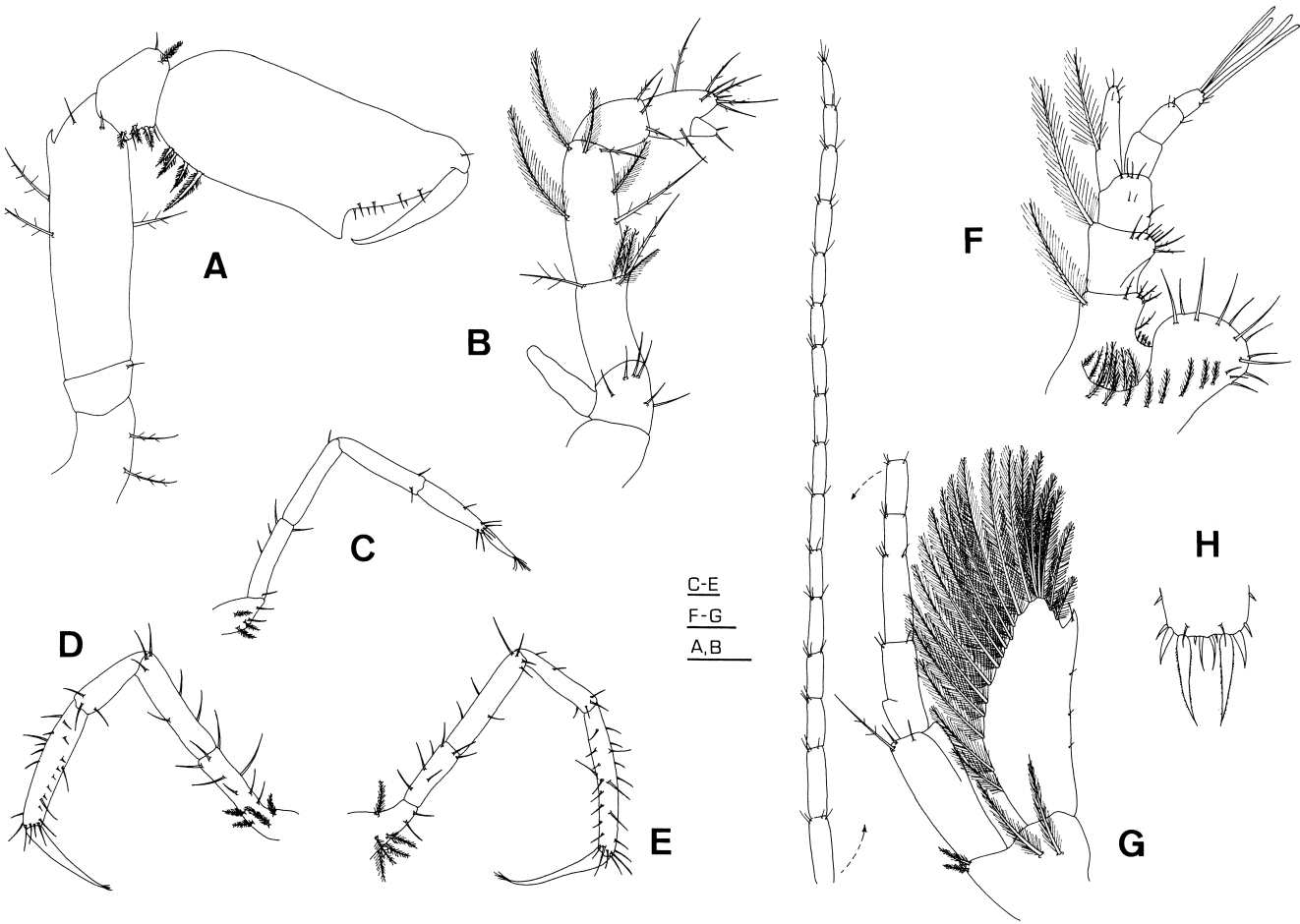

Fig. 13. Philocheras monacanthus. First juvenile stage: A, first pereiopod; B, second pereiopod; C, third pereiopod; D, fourth pereiopod; E, fifth pereiopod; F, antennule; G, antenna; H, telson. Scale bars $=100 \mu \mathrm{m}$. 
(D’Udekem d'Acoz, 1992; Barnich, 1996). In such regions the larvae and adults of these two species are difficult to distinguish because $P$. bispinosus has intermediate forms. We agree with Pessani and Godino (1991) that studies on environmental and genetic factors in species of the genus Philocheras would be of great benefit in better understanding the relationships of this group of shrimps.

\section{ACKNOWLEDGEMENTS}

This research was financially supported by Acuerdo de Cooperación Bilateral entre el Consejo Superior de Investigaciones Científicas (CSIC) de España y el Instituto de Cooperação Científica e Tecnológica International (ICCTI) de Portugal (Ref: SGRI/MDH-98).

\section{LiTERATURE CITED}

Anger, K., E. Spivak, C. Bas, D. Ismael, and T. Luppi. 1994. Hatching rhythms and dispersion of decapod crustacean larvae in a brackish coastal lagoon in Argentina.-Helgoländer Meersuntersuchungen 48: 445-466.

Barnich, R. 1996. The larvae of the Crustacea Decapoda (excl. Brachyura) in the plankton of the French Mediterranean coast (identification keys and systematic review).-Ph.D. thesis, Münster University, Göttingen, Germany. Pp. 1-189.

Clark, P. F., D. K. Calazans, and G. W. Pohle. 1998. Accuracy and standardization of brachyuran larval descriptions.- Invertebrate Reproduction and Development 33: 127-144.

Christiansen, M. E. 1973. The complete larval development of Hyas araneus (Linnaeus) and Hyas coarctatus Leach (Decapoda, Brachyura, Majidae) reared in the laboratory.-Norwegian Journal of Zoology 21: 63-89.

D’Udekem d'Acoz, C. 1992. A propos de trois Crustacés décapodes nouveaux pour la faune Portugaise: Philocheras monacanthus (Holthuis, 1961), Pachygrapsus transversus (Gibbes, 1850) et Macropodia czernjawskii (Brandt, 1880).--Archivos do Museo Bocage, nova serie, 11: 127-136.
Gurney, R. 1903. The larvae of certain British Crangonidae.-Journal of the Marine Biological Association of the United Kingdom 6: 595-597.

Kurian, C. V. 1956. Larvae of decapod Crustacea from the Adriatic Sea.-Acta Adriatica 6: 1-106.

Nöel, P. Y. 1992. Clé preliminaire d'identification des Crustacea Decapoda de France et des principales autres espèces d'Europe.-Muséum national d'Historie naturelle, Collection Patrimoines Naturels 9: 1-145.

Lavalli, K. L., and J. R. Factor. 1992. Functional morphology of the mouthparts of juvenile lobsters, Homarus americanus (Decapoda, Nephropidae), and comparison with the larval stages.-Journal of Crustacean Biology 12: 467-510.

Lebour, M. V. 1931. The larvae of the Plymouth Caridea. I. The larvae of the Crangonidae. II. The larvae of the Hippolytidae.-Proceedings of the Zoological Society of London 1931: 1-9.

Pessani, D., and C. Godino. 1991. Larval development of Philocheras trispinosus (Hailstone, 1835) (Decapoda, Crangonidae) reared in the laboratory.-Journal of Crustacean Biology 11: 123-137.

Pike, R. B., and D. I. Williamson. 1961. Larval variation in Philocheras bispinosus (Hailstone) (Decapoda, Crangonidae).-Crustaceana 2: 21-25.

Queiroga, H., J. D. Costlow, and M. H. Moreira. 1994. Larval abundance patterns of Carcinus maenas (Decapoda, Brachyura) in Canal de Mira (Ria de Aveiro, Portugal).-Marine Ecology Progress Series 111: $63-72$.

Sars, G. O. 1890. Bidrag til kundskaben om decapodernes forvandlinger.-Archiv for Mathematik og Naturvidenskab 14: 132-195.

Webb, G. E. 1921. The larvae of the Decapoda Macrura and Anomura of Plymouth.- - Journal of the Marine Biological Association of the United Kingdom 12: 385-425.

Williamson, D. I. 1960. Crustacea Decapoda: Larvae VII. Caridea, Family Crangonidae. Stenopodidea.Fiches d'Identification du Zooplancton 90: 1-5.

Williamson, H. C. 1915. VI. Crustacea Decapoda: Larven.-Nordisches Plankton 18: 315-588.

RECEIVED: 5 March 1999.

ACCEPTED: 16 June 1999. 